UDC 101.37.71 (477)

DOI: $10.26565 / 2226-0994-2020-62-22$

Galina Zhukova

\title{
PHILOSOPHICAL REVELATION OF NON-ACADEMIC EDUCATION FORMS
}

The non-academic education as the development of socio-cultural experience that takes place outside the pedagogically organized process is considered in the article. The freedom of human cognitive activity, the expansion of the range of his hobbies, the enrichment of the spiritual world is ensured through a network of institutions of non-academic education. Non-academic education institutions transfer the knowledge and skills necessary in the field of work, which does not belong directly to the scientific content of professional activity. The term "non-academic education" is not yet widespread, it is used mainly by practitioners in the field of solving general problems of education, based on human educational needs. However, the reality it reflects is well known to all, it is learning in the process of daily life. In essence and content, it is the same process of acquiring knowledge and skills, deepening worldview and enriching personal potential, which is in academic education. The difference is that it takes place outside the walls of institutions that are part of the education system. Non-academic education takes place in social institutions that perform other functions in the social division of labor: in the family, in the field of work, in various formal and informal groups and associations. A clear training goal is not necessary. Non-academic education is spontaneous, without time limits, not certified, unlike academic. Non-academic education may have some kind of documentary evidence, albeit of a non-state type. A teacher in academic education is necessarily an employee of an educational institution, and in non-academic education it is an employee, a coach, and a teacher. Training in non-academic education can be carried out on the educational portal through social services, distance learning courses of various organizations, mass open courses.

Keywords: non-academic education, distance learning, online courses.

Professional development of a person is the acquisition of specific qualities that are defined by the social environment. Its self-realization is directly related to the degree of contribution that a person makes to the cause of others, which is the deep meaning of human existence. The modern development of education, on the one hand, causes alarming tendencies to interrupt educational continuity, impoverishes the inner world of the young generation, alienates young people from ideals and values, on the other hand, it gives meaning to life in meeting the educational needs of the individual. The boundaries of academic education have become narrow to achieve the modern quality of education, in this regard, the study of non-academic education, which is represented by training, seminars, individual training, and others, is relevant.

The aim of the article is to reveal the forms and functions of non-academic education. The task, respectively, is to study the features of distance learning as a form of non-academic education.

People learn and transform the existing socio-cultural experience in society not only within the walls of educational institutions. Many forms of learning were practiced before, when there were no specialized institutions or specially trained teachers. These can be developments of teachers and online communities, self-correction of tasks using the Internet, visiting virtual galleries, museums, online communication with colleagues, friends, and participation in the work of virtual communities of practice. Scientists O. Kyvliuk [Kyvliuk, 2018], S. Klepko [Klepko, 2011], O. Lazarenko [Lazarenko, 2011], L. Rybalchenko [Rybalchenko, 2018] and others worked on this problem.

The modern world educational community is actively developing and supporting non-academic education, according to the fact that the time period of knowledge aging has been reduced to five years in recent years. That is, the information that a specialist received while

(C) Zhukova G. V., 2020.

(cc) Br This is an open-access article distributed under the terms of the Creative Commons Attribution License 4.0. 
studying at a higher education institution before graduating from university becomes irrelevant. In the practical professional sphere, the same thing happens: the rapid introduction of innovative technologies in production, banking, finance and other areas forces employees of enterprises and firms to constantly improve their skills. Therefore, non-academic education is becoming a necessary and increasingly important element of modern educational systems. Currently, any person has the opportunity to enter educational institutions regardless of their place of residence and basic education, to study remotely and improve their skills in a particular area.

The variety of forms in which educational activities take place due to the differentiation of goals and objectives of education in the direction of more active participation of the subject: on-line consultations, distance learning, mobile learning, forums, e-portfolios, interactive workshops, webinars, facilitation, interactive lectures, meta-learning. On-line training and consulting is the best way to gain new knowledge and skills for professionals from other cities and countries in a convenient location and at a convenient time. You can learn from certified developers and trainers on Skype, video tutorials or mobile devices. During the study, the student receives all the teaching materials of the course, hears, sees the teacher, presentations, performs practical tasks. The student's electronic portfolio is a tool for self-assessment of cognitive work and reflection of his own activities, a special educational space where students and teachers work together to accumulate, systematize, analyze and present their results and achievements over a period of time. With the informatization of society, further development of information and communication technologies, in educational institutions there was a transition from the development of paper versions of the Portfolio to its electronic versions.

An example of non-academic education is the innovative project "Gender Open University", which was created by the Center for Gender Culture on the basis of the Municipal Institution "Kharkiv Humanitarian and Pedagogical Academy" of the Kharkiv Regional Council and the State Penitentiary Service of Ukraine in Kharkiv region. This is a new gender project, one of the activities of which is to equip workers with gender knowledge. A system of gender projects is being created that focuses on the needs of professional activities with the support of a vulnerable population. Its implementation ensures the dissemination of the principles of gender equality, social responsibility and education of all existing organizations. Working meetings are held during which the participants are informed, plans for interaction, prospects, missions and the program of the pilot training course "Gender Open University" are developed [Gender Open University..., 2020].

In 2008, Canadian researchers Stephen Downs and George Siemens created an online course on connectivism (one of the approaches to artificial intelligence) and related knowledge, and coined the name MOOC (Massive Open Online Courses). They were available and free for everyone, they signed up more than two thousand people. The course industry, as well as their audience, has grown significantly since then, and many of the world's leading universities are actively working to create and support online courses. Among the leaders of this movement are the American universities of Harvard, Stanford and the University of Massachusetts, which attract several hundred thousand students to their courses, and more and more countries and universities are catching up with this trend. MOOC platforms are being actively created in Europe, Asian countries and Australia. MOOC can generally be divided into two categories: cMOOC and xMOOC. cMOOC are based on the theory of teaching connectivism, which emphasizes the power of networking with other people, gathering different opinions and focusing on the final causes as the foundation of learning. Later, the concept of these courses has changed, and the name has changed accordingly - xMOOC. They are a combination of pre-recorded video lectures with quizzes, tests, grades, centered on the professor, not the students [cMOOC versus xMOOC, 2017].

Examples of Mass Open Online Courses are Coursera [Coursera, 2020], EdX [EdX, 2020], Udacity [Udacity, 2020]. In 2013, the first Mass Open Online Courses were opened in Ukraine on the basis of the Taras Shevchenko National University of Kyiv. At the National Technical University "Kharkiv Polytechnic Institute" there are distance courses for 
university teachers. These courses cover innovative developments and a detailed explanation of the basics of some disciplines [Distance courses for teachers..., 2020].

In the European educational discourse, the conviction is formulated that academic education is no longer able to meet the challenges of society using only its own strengths and values; therefore, such education should be improved by non-academic educational practice. In modern concepts of education, there is a concept that considers education as a learning process that lasts throughout life, in contrast to the traditional concept, where education is obtained mainly during the period of formal school and university education. Modern society requires new skills, additional knowledge, promotion of social equality, access to education for all and active participation in a democratic life. This fact provides a place for the emergence of non-academic education. Academic and non-academic education are complementary, they exist simultaneously. Elements of one type of education can be found in another.

A person acquires knowledge, abilities and skills in different ways. In this case, the experience of participating in various activities and in the course of interpersonal contacts, which leave their mark on understanding life problems and on the choice of ways to solve them, is of great importance. This experience can be positive or negative, however, the results of such training are, in a certain sense, one of the indicators of education that are not taken into account in a formalized way. Non-academic education as a social institution a vast deal of promotes to the classification of ways a person's socio-cultural experience. It is a specific non-institutional form of acquiring knowledge and skills. We are talking about adults whose education is related to their vital interests. As such a criterion, we can suggest possible positive changes in the social status of the subject after a certain period of life, training in courses.

Penetration into the educational system of non-academic essence and principles as one of the components of the improving education process provides for greater accessibility of education for all groups of the population, increasing the creative component in education, and ensuring the focus of training on new information technologies. The needs of modern society require updating the content and technologies of education; suggest the key role of education in ensuring dynamic development. The current stage in the development of science is significant in that society is entering the period of obtaining and transmitting knowledge related to the development of information and telecommunication technologies. Currently, a type of training has been introduced that involves the use in teaching traditional and innovative educational programs with appropriate methods. This concept combines the flexibility and effectiveness of e-learning, providing complete non-academic education. The teacher must possess not only scientific, educational and communicative competencies, but also information technology.

Thus, we can conclude that the generation of a large amount of information in cyberspace leads to the need to implement the concept of non-academic education. It makes it possible to conduct the educational process both inside and outside the official educational institutions, and also creates the want for continuous training of adults depending on the requirement for new knowledge. The requisite for non-academic education is dictated by constant changes in the fields of economics and business, which ensures the most effective organization of the learning process. Non-academic education does not replace academic education but is a mechanism that ensures the effective development of learning.

\section{REFERENCES}

Gender Open University: Gender Literacy and the Culture of Social Workers. (2020). Center for Gender Culture. Retrieved from http://www.genderculturecentre.org/genderniy-vidkritiyuniversitet-ge.

cMOOC versus xMOOC. (2017, October 25). SlideShare. Retrieved from https://www.slideshare. net/Marcobertolini/cmooc-versus-xmooc.

Coursera [Website]. (2020). Retrieved from https://www.coursera.org.

Distance Courses for Teachers of the National Technical University "Kharkiv Polytechnic Institute” [Website]. (2020). Retrieved from http://dl.khpi.edu.ua. 
$E d X$ [Website]. (2020). Retrieved from https://www.edx.org.

Klepko, S. (2011). Ontological Problems in the Subject Field of Philosophy of Education. Philosophy of Education, 1-2(9), 174-193. (In Ukrainian).

Kyvliuk, O. (2018). Media Education. In V. P. Andrushchenko (Ed.), Philosophy of Education (pp. 168-174). Kyiv: NPU named after M. P. Dragomanov. (In Ukrainian).

Lazarenko, O. (2011). Philosophy of Adult Education in the Context of the Practical Paradigm of Lifelong Learning: A European Example for Ukraine. Philosophy of Education, 1-2(10), 255-265. (In Ukrainian).

Rybalchenko, L. V., \& Silina, I. S. (2018). Distance Learning: World Experience and Use in Ukraine. In Formation of a Modern Management Model and Improving the Quality of Management in the Higher Education System (Dnipro, 2018). International Scientific-Practical Conference Proceedings (pp. 257-260). Dnipro: University of Customs and Finance. (In Ukrainian).

Udacity [Website]. (2020). Retrieved from https://www.udacity.com.

Zhukova Galina V.

$\mathrm{PhD}$ in Pedagogy, Doctoral Student

Senior Lecturer of the Department of Preschool Education

National Pedagogical Dragomanov University

9, Pirogov str., 02000, Kyiv, Ukraine

E-mail: galinazh1299@gmail.com

ORCID: https://orcid.org/0000-0002-1248-4669

Article arrived: 07.05.2020

Accepted: 08.06.2020

\section{ФІАОСОФСЬКЕ РОЗКРИТТЯ ФОРМ ПОЗААКААЕМІЧНОЇ ОСВІТИ}

\section{Жукова Галина Вікторівна}

кандидатка педагогічних наук, Аокторантка

старша викладачка кафедри методик та технологій дошкільної освіти

Національний педагогічний університет імені М. П. Арагоманова

вум. Пирогова, 9, Київ, 02000

E-mail: galinazh1299@gmail.com

ORCID: https://orcid.org/0000-0002-1248-4669

У статті розглядається позаакадемічна освіта як напрям розвитку соціокультурного АосвіАу, який вілбувається поза педагогічно організованим процесом. Свобода пізнавальної діяльності Аюдини, розширення кола іiі захоплень, збагачення духовного світу забезпечується через мережу закладів позаакадемічної освіти. Позаакадемічні навчальні заклади передають знання та вміння, необхіАні в галузі праці, які не належать безпосередньо до наукового змісту професійної Аіяльності. Термін “позаакадемічна освіта" ще не набув широкого поширення, він використовується переважно практиками в галузі розв’язання загальних проблем освіти на основі освітніх потреб Аюдини. ОАнак реальність, яку вона відображає, добре відома всім - це навчання в процесі повсякденного життя. За сутністю та змістом це той самий процес набуття знань і вмінь, поглиблення світогАяАу та збагачення особистісного потенціалу, який є в академічній освіті. Різниця полягає в тому, що позаакадемічна освіта здійснюється поза стінами закладів, що входять Ао системи освіти. Позаакадемічна освіта віАбувається в соціальних установах, які виконують інші функції в соціальному поділі праці: у родині, у галузі праці, у різних формальних і неформальних групах і об’єАнаннях. Чітка мета навчання тут не потрібна. Позаакадемічна освіта, на відміну віА академічної, є спонтанною, здійснюється без обмежень за часом, не є сертифікованою. Позаакадемічна освіта може мати певне документальне піАтвердження, хоча й недержавного зразка. Учитель в академічній освіті - це обов’язково працівник навчального заклаАу, а в позаакадемічній освіті - це працівник, тренер і викладач. Навчання у позаакадемічній освіті може здійснюватися на освітньому порталі через соціальні служби, Аистанційні курси різних організацій, масові віАкриті курси.

Ключові слова: позаакадемічна освіта, Аистанційне навчання, онлайн-курси. 